\title{
Technology, Society and the Digital Gap
}

\author{
Yaron Katz \\ Holon Institute of Technology, Holon, Israel \\ Email: yaron@ykatz.com
}

How to cite this paper: Katz, Y. (2019). Technology, Society and the Digital Gap. Advances in Applied Sociology, 9, 60-69. https://doi.org/10.4236/aasoci.2019.91005

Received: November 5, 2018

Accepted: January 12, 2019

Published: January 15, 2019

Copyright (c) 2019 by author(s) and Scientific Research Publishing Inc. This work is licensed under the Creative Commons Attribution International License (CC BY 4.0).

http://creativecommons.org/licenses/by/4.0/

\begin{abstract}
What is more influential-technology or society? While this issue has been in constant dilemma for many researches, the situation in Israel is clear: Israel is a leading high-tech country and technology is leading society in all aspects. In terms of technology, Israel is a technologically advanced market economy. It is known as a "Start-up Nation", which means that its economic growth is stupendous and leading in high-tech worldwide. On the other hand, Israel is among the most impoverished of the OECD member countries, with a high rate of poverty and a social and digital big gap between its rich and poor. The main issue that this research investigates is the social gap of a developed country and a leading start-up nation which falls behind many countries in major social and policy categories. As the research demonstrates, Israel is a prime example of the domination of technology over society. The country's development is a product of the digital revolution which situates Israel as a developed country in terms of technology, however also has been negative for the socio-economic inequality, to what this research defines as the digital gap.
\end{abstract}

\section{Keywords}

Technology, Society, Israel, Digital Gap, Social Gap

\section{Introduction}

Definition of technology and society is not easy when we consider all the aspects and characteristics of this complex issue (Kumar, Kumar, \& Persaud, 1999). In examining the impact of technology on our lives, there is no doubt that the information age led to a complete revolution in how we communicate and receive information (Castels, 2015). Technology plays a large role in globalization on a cultural, political and economic level, as it enables global domination of Western cultural and economic values, while breaking down of cultural and economic borders (Mckenzie, 2015). However, while technology and globalization have great and positive impact, they have also been negative for the socio-economic 
inequality, creating Digital Gap between countries and within countries. The socio-economic inequality creates ethnic, religious and political differences within countries, including income inequality, and major differences in the way developed and developing countries cope with global competition.

Digital Gap is the result of technological and global processes: the advancements and improvements in technology are provoking differences between workers with high skills and those with lower skills, while globalization caused the adoption of new technologies in a way that workers that are not prepared or don't know how to use new technologies are penalized (OECD, 2011). The Digital Gap Act became the official policy of the State Department and USAID, aimed to expand internet access in developing countries to help reduce the digital divide with the developed world (H.R. 600).

The digital gap is a key aspect of Israel, which can be considered a developed country in technological advancement (US News, 2017). The digital gap means that Israel is leading global competition in high-tech and innovation (OECD, 2016), with the largest number of start-up companies globally, second only to the USA (Senor and Singer, 2009). However, although it has a strong economy, there are income inequality, financial gaps and lack of social unity among the different segments of society, creating major social and digital gaps. Income inequality is among the highest in the Western world and the poverty rate and income gap between classes are similarly high (Keeley, 2015).

In terms of technological development, the country is ranked $10^{\text {th }}$ in most innovative countries (Jamrisko \& Lu, 2018). According to the Israel Innovation Authority (2018), innovation is by far the most valuable resource for Israel, serving as a national asset crucial to economic prosperity, and strengthening the innovation ecosystem would further develop and support technological innovation in Israel. The technological advantage of Israel has promoted its economy, which has grown as a result more rapidly than most other advanced economies. Israel is leading global competition, as high-tech development is based on leadership in innovation (OECD, 2018) and the Israeli economy is enjoying its 15 th consecutive year of growth (Ackerman, 2018). According to OECD Economic Surveys (2018), with the benefit of technology, the economy continues to register remarkable macroeconomic and fiscal performance.

But on the other hand, according to OECD report, Israel is second only to the United States among developed nations in inequality (OECD, 2011). Another OECD report which examined income inequality and the gap between the richer and the poorer segments of society in member states, found that Israel is ranked in $1^{\text {st }}$ place with the highest percentage of people living below the poverty line. It is also ranked 3rd in income inequality (OECD, 2016). Even though efforts made into shrinking the socio-economic gap among the population, Israel is still one of the most unequal economies. It has a very small rate of unemployment and high economic growth, however, the issue of inequality and socio-economic differences among the different groups of the population is still relevant and disturbing (Dattel \& Maor, 2015). 
The research examines the impact of technology on the development of the digital and social gap in Israel-claiming that technological development, which is the leading aspect of the Israeli economy, has also caused inequality among the different groups of the Israeli society and created major social differences in the way the country is developing.

\section{Country of Immigrants}

Israel has been, and still is, a country built by immigrants (Wilfried Marshal Center, 2013). People from all around the world make up Israeli society, which is a diverse society-ethnically, culturally and economically. Since its establishment in 1948, Israel's demographics have shifted greatly due to large immigrant waves (Schafferman, 2008). This increases the socio-economic division, since immigrants that arrived from Asia and Africa had a lower level of education and some disadvantages both socially and economically in comparison to immigrants that came from Europe or America (Kaplan, 2015). Each of the immigrant groups assembling Israeli society adopted a different way in its assimilation into Israeli society (Schafferman, 2008), creating gaps between immigrant groups.

According to the Central Beareu of Statistics, in 2017:

Israel's population-8,680,600 people: 6,484,000 (74.7\%), 1,808,000 Arabs (20.8\%), 4.4\% with no religion.

Born in Israel-76\%.

Immigrants from Europe and the Americas-16\%.

Ashkenazi Jews (their families came from Europe and the Americans)-approximately $50 \%$.

Mizrahi Jews (their families came from Arab and Muslim countries)-approximately $50 \%$.

The socio-economic gap is one of the most important issues that encourage the struggle in Israeli society, including differences in income and educational level. This gap affects mainly Ultra-Orthodox (Haredim) and Israeli-Arabs (Katz, 2007). This view is supported by the findings of the Israel Democracy Institute, since the number of Haredim reached one million in 2017, representing 12 percent of the population, and the Haredi sector is projected to comprise $16 \%$ of the total population by 2030 . It will constitute a third of all citizens and $40 \%$ of the Jewish population in 2065. Although the Haredi society is undergoing big changes, with greater participation of both women and men in the workforce (Temkin, 2018), there remains a significant wage gap relative to non-Haredipopulation (Elis, 2016).

The Haredi society is extreme about religious faith. The Haredi leadership lives in a state of threat from spiritual, social, cultural and political phenomena that surround the community. These basic assumptions lead the community in all life aspects: clothing, education, marriage matchmaking and even language. The cultural segregation and sectorial coherency of the community are aimed to 
protect Jewish culture from western culture and secularism. The religious and ideological gap between the Haredi society and the general society distanced the community from other sectors (Cohen, 2006).

Most people in the ultra-religious sector live below the poverty line. Despite their cultural segregation, the sector has great political influence and thus many young members of the community do not serve in the army and learn Torah with their salary paid by the government. The position of the community against equal service in the Israeli army (IDF) has created wide opposition in the general population and isolation of the community from the Israeli society as a whole. This position has damaged the Haredi community, since it is considered poor as most of those who do not participate in the work force are poor (Kimberling, 2003). It also creates difficulties to the economy-since with the high growth rate of the community, Israel could become a third world country-where the wealthy secular majority supports the growing minority. Former Governor of the Bank of Israel, KarnotFlug, warns that employments rates for Haredimen are particularly low, particularly due to education trends-as the rate of higher education among the Ultra-Orthodox population is particularly low. She explains that the way to integrate successfully in the labor market is to obtain an academic education, as those holding degrees enjoy much higher rates of employment and much higher wage levels than those who do not hold such a degree (Flug, 2014).

The other low sector in Israel is the Arab community. Digital gap between Jews and Arabs originate from their cultural background. Israeli-Arabs are a unique minority indigenous group with two affinities - to Israeli modern society (because of citizenship) and to the Arab traditional world (because of their religious and cultural roots) (Boudreaux, 2008). Closing digital gaps requires changes in basic social, economic, and cultural aspects of the Arab sector (Lissista, 2014) although the Arab community is divided into subgroups - Muslims, Christians and Druze. The Christians are further divided into subgroups, and among the Muslims there are the Bedouin. So to a typical Israeli, the Arabs are merely a collection of non-Jewish religious and ethnic communities which live in a different social structure and economic structure (Khoury, 2017). According to the Israel Democracy Institute's Peace Index, 55\% of Israeli Arabs are proud citizens of Israel, but $76 \%$ reject its definition as a 'Jewish state'. $73 \%$ of Israeli Arabs feel a sense of belonging and $60 \%$ are proud to be Israelis (Ron, 2017).

The digital gap of the Israeli-Arab community in evident in the workforce. The hi-tech industry comprises one-twelfth of the Israeli workforce, or slightly more than $8 \%$ of all workers, but Israeli Arabs constitute $20 \%$ of the population with only around $1 \%$ of the employees in the industry (Brand, 2017). Recently the Knesset committee for Arab Affairs approved a NIS 20 million (\$5.6 million) two-year plan for the creation of technology parks within Arab towns in Israel, as a way to boost local employment opportunities locally and close income gaps between Jewish and Arab Israelis (Solomon, 2018).

The Arab Bedouin minority of the Negev is one of the most discriminated 
groups within the Arab population and within Israeli society as a whole. According to the Association for Civil Rights in Israel, more than half of the approximately 160,000 Negev Bedouins reside in unrecognized villages, which the state refuses to provide with a planning structure and place under municipal jurisdiction. About half of them live in seven government-built Bedouin-only towns; and the remaining in 46 villages-most of them are unrecognized officially. These villages lack basic services such as running water, electricity, telephones, roads and public institutions. As a result, the Bedouin population suffers from high unemployment rates $(25 \%-30 \%)$, vast poverty rates $(60 \%$ of the children in the Bedouin sector are poor) and low salaries (Lisistsa, 2014).

\section{Technology Growth and Social Difficulties}

As the research demonstrates, the growth of the technology sector has been counter to the social difficulties in Israel, and the prosperity of the country based on the success of technology causes a major social gap (Poch, 2016). Accordingly, researches and policymakers argue that the social and digital gap is threatening the leading role of technology and the strength of the Israeli economy and high-tech sector.

According to former Governor of the Bank of Israel, KarnitFlug, poverty among Ultra-Orthodox households (47 percent) and Arab households (54 percent) is much higher than among the general population (12.5 percent). These trends are a result of the relatively low labor force participation and education levels. As she explains, the gaps are dangerous to the economy: the achievements of the Israeli education system have been lower than the OECD average, which is certainly a worrying situation for a country whose growth strategy is based on human capital (Flug, 2014). According to Schejter and Tirosh (2016), narrowing Israel's digital gap would reduce socioeconomic inequality, since technology needs to create a policy that ensures access to marginalized groups and to modern aspects of society and help them to utilize the potentials of new media. However, as explained by Tenkin (2018), the source of the problem is low level of skills taught to children in these groups and lack of programs for improving their capabilities. Israel's National Insurance Institute released its annual Poverty Report at the end of 2017, showing overall improvements in the reduction of poverty and inequality, but still, relative to other developed countries, Israel status remains troubling, having the highest poverty rates among OECD member states (Israel's Annual Poverty Report, 2018).

Israel is a country that is characterized by high levels of economic inequality, poverty, and social diversity (Khattab, Miaaru, \& Steir, 2016). According to the Israeli National Central Bureau of Statistics, poverty rate stands at 20.9 percent-the highest among OECD countries and fifth in terms of income inequality. The annual OECD Employment report shows that the workforce in the top (90th percentile) in Israel earned 7.22 times higher than those in the bottom (Sade, 2018). The economic contribution of the flourishing high-tech sector does not always spill over into other sectors of the economy (Unesco Science Report, 
2015) and as a result the growing socio-economic gap that has resulted from the structure of the economy and the concentration of wealth among the upper $1 \%$ is having a destabilizing effect on society (Brodet, 2008).

According to OECD Economic Survey, despite the fact that Israel's economy continues to register remarkable macroeconomic and fiscal performance, Israeli society remains marked by weak social cohesion and significant disparities, which penalize parts of the population and threaten the longer-term sustainability of these good results. The survey explains the outcome of the digital gap: despite better employment outcomes among Israeli-Arabs and the Haredim, workers from these communities are often trapped in low-paid jobs due to their weak skill sets, implying persistent poverty and weak aggregate productivity. Moreover, low social transfers imply that the often large families in these communities face deprivation that contributes to child poverty. High cost of living and house prices also weigh on the social situation and well-being, and public transport deficiencies are detrimental to work-life balance and cause urban congestion and poor air quality. The survey found that making growth stronger, more inclusive and more sustainable will require further action and more public investment in education to improve the skills of Israeli-Arabs and Haredim together with additional product market reforms and better transport infrastructure (OECD, 2018).

According to a study conducted by the National Economic Council, Israel must take steps to ensure rates of inequality and poverty. The authors warn that "a large economic, social or security crisis can add fuel to a fire that there is no coming back from". They found that Israel has not yet passed the point of no return, but is heading in that direction because of economic issues that have been neglected for years (Margalit, 2017). Israel is likely to see slow economic growth due primarily to an increase in population groups with high unemployment rates and low skill sets, according to a report by the Taub Center for Social Policy Studies in Israel (Grave-Lazi, 2015).

The digital gap is defined by the Israeli Parliament (Knesset) as the gap in the exposure to the world of computers. According to a report by a Parliamentary Committee of Inquiry on the Issue of Social Gap in Israel (2002), the inequality in socioeconomic resources is one of the reasons for the digital gap, side by side with conservatism, fear of technology and lack of interest. The report found that the digital gap itself causes an accentuation of the socio-economic inequality, as the more prosperous strata have greater access to the world of computers, which provides them with a relative advantage in the world of education, knowledge, culture and employment. According to the report, the findings ought to shake the foundations of the government, political, academic, and media system, as a harsh overall picture emerges from the combined concentration of growing economic and social gaps in many spheres. The committee found that Israel is graded in second place in the Western world in terms of the size of the gaps in income and in the prevalence of poverty, and concluded that the main explanations for this phenomenon is the acceleration of the globalization process and 
the effects of the technological and communications revolution.

Thus, it is fair to say that Israeli policymakers accept the fact that a digital and social gap persists between different groups is apparent, although claim that technology and free market can cure these gaps. Prime Minister Benjamin Netanyahu says: "Israel is rapidly becoming a global high-tech superpower while combining free market and advanced technology. But without free market, lower taxes and lesser bureaucracy, we will not reach that goal and get nowhere, and for that reason we combine the two aspects of our policy-advanced technology and free market". In a meeting of the Knesset Interior Committee which approved the reform in business licensing, Netanyahu added: "I received IMF data according to which Israel has surpassed the average per capita income and the reason is because we have led a free economy here. If we did not do this we would be in a completely different situation. We have turned Israel into a free economy and thus everything has begun to flourish". However, analysts from the IMF and the Organization for Economic Co-operation and Development (OECD) warn that unless Israel makes more headway in reducing social and educational gaps in the ultra-Orthodox and Arab sectors, Israel's economic growth and competitiveness will falter. Netanyahu responds to that proposition in that Israel is a state of "full employment"-which means that the economy is such that all eligible people who want jobs can get one, implying that the weak segments of society do not fully participate in the labor market by choice (Schindler, 2018).

\section{Conclusion}

Domination of technology is what identifies most the Israeli over society. The country's development is based on the digital revolution and is a developed country in terms of technology. However, it is has major social and policy issues-a contradiction that results in digital gap. The research examines counter relations between technology and society and the digital gap that characterizes Israel as a high-tech country where technology has largely expanded. This gap creates an interesting situation fueled by social contrasts: a developed country in terms of technology and a developing society, or, in other words, a developed and successful economy with high rates of poverty. As the research demonstrates, Israel has a highly developed technology sector and it is one of the most innovative economies in the world, although technology has had an enormous impact on the Israeli economy, it is also negative for the socio-economic gaps and for inequality. Poverty rates in Israel are among the highest in the rich world, mainly among the ultra-Orthodox community and Arab citizens, and despite efforts by the government to shrink the socio-economic and digital gaps, Israel is still one of the most unequal economies.

Looking at the future, the digital gap needs to be reduced to allow Israel to become a truly developed country. The research looks at the technological impact on society and concludes that the role technology plays in reducing the gap is enormous. It seems that the digital gap is the result of technological and global 
processes, and once all parts of society can be exposed to the impact of technology and globalization, the gap can be dealt with for the poor segments of society. To reach this goal, differences between workers should be reduced to allow the poor segments to acquire the skills that would allow them to benefit from the supremacy of technology in Israel. As concluded by the research, in order to reach this goal, a government plan is required-although previous government plans have not succeeded to reduce the digital gap.

\section{Conflicts of Interest}

The author declares no conflicts of interest regarding the publication of this paper.

\section{References}

(2015). UNESCO Science Report: Towards 2030.

http://unesdoc.unesco.org/images/0023/002354/235406e.pdf

(2018). Israel's Annual Poverty Report: Poverty Decreased in Arab Society but Rates Remain High.

Ackerman, G. (2018). Behind Israel's High-Tech Reputation Is a Low-Tech Economy, Bloomberg.

https://www.bloomberg.com/news/articles/2018-02-14/israel-s-low-tech-economy-beli es-reputation-as-global-tech-hub

Boudreaux, R. (2008). ISRAEL: Digital Gap between Arabs and Jews. Los Angeles Times, February 26, 2008

http://latimesblogs.latimes.com/babylonbeyond/2008/02/israel-digital.html

Brand, G. (2017). State of the Nation 2017: A Macroeconomic Picture of the Economy in 2017. Taub Center, December 21, 2017.

http://taubcenter.org.il/state-of-the-nation-report-2017-pr/

Brodet, D. (2008). Israel 2028: Vision and Strategy for the Economy and Society in a Global World. Presented by a Public Committee Chaired by Eli Horvitz. US-Israel Science and Technology Foundation.

Castels, M. (2015). The Impact of the Internet on Society: A Global Perspective. https://www.technologyreview.com/s/530566/the-impact-of-the-internet-on-society-aglobal-perspective/

Cohen, Y. (2006). The Religious-News Media Nexus in Israel. Sociological Papers No 112, Israel: Social Institute for Community Studies, Bar Ilan University.

Elis, N. (2016). Wage Gap between Haredi, Non-Haredi Women Persists. Jerusalem Post, April 17, 2016.

https://www.jpost.com/Business-and-Innovation/Wage-gap-between-haredi-non-hare di-women-persists-451497

Flug, K. (2014). Strengths and Challenges Facing the Israeli Economy: Main Points of Remarks by Dr. Karnit Flug, Governor of the Bank of Israel, at the Jerusalem UItra-Orthodox Campus of Ono Academic College, Jerusalem.

https://www.bis.org/review/r141208j.htm

Grave-Lazi, L. (2015). Bridging the Gaps in Israeli Society through Technology. The Jerusalem Post.

http://www.jpost.com/Israel-News/Bridging-the-gaps-in-Israeli-society-through-techn ology-394188

H.R. 600 (2017) 115th Congress 1st Session, in the Senate of the United States January 30, 
2017. https://www.markey.senate.gov/imo/media/doc/DIGITAL\%20GAP\%20Act.pdf

Israel Innovation Authority (2018).

Jamrisko, M., \& Lu, W. (2018). The U.S. Drops Out of the Top 10 in Innovation Ranking. https://www.bloomberg.com/news/articles/2018-01-22/south-korea-tops-global-innova tion-ranking-again-as-u-s-falls

Kaplan, J. (2015). Introduction: The Diversity of Israeli Society. The Jewish Agency. http://www.jewishagency.org/society-and-politics/content/36171

Katz, Y. (2007). The Other Media-Alternative Communications in Israel. International Journal of Cultural Studies, 10, 383-400. https://doi.org/10.1177/1367877907080150

Keeley, B. (2015). Income Inequality, the Gap between Rich and Poor. OECD. http://www.oecd.org/social/income-inequality-9789264246010-en.htm

Khattab, N., Miaari, S., \& Stier, H. (2016). Socio-Economic Inequality in Israel: A Theoretical and Empirical Analysis.

Khoury, J. (2017). Arab Citizens Want to Integrate into Israel but Refuse to Be a Trampled Minority. Haharetz.

https://www.haaretz.com/israel-news/.premium-arab-citizens-want-to-integrate-into-i srael-1.5628291

Kimberling, B. (2003). The Israeli State and Society. State University of New York Press.

Kumar, V., Kumar, U., \& Persaud, A. (1999). Building Technological Capability through Importing Technology: The Case of Indonesian Manufacturing Industry. Journal of Technology Transfer, 24, 81-96. https://doi.org/10.1023/A:1007728921126

Lissista, S. (2014). Patterns of Digital Uses among Israeli Arabs-Between Citizenship in Modern Society and Traditional Cultural Roots. Asian Journal of Communication, 25, 447-464. https://doi.org/10.1080/01292986.2014.981555 https://www.tandfonline.com/doi/abs/10.1080/01292986.2014.981555?journalCode=raj c20

Margalit, M. (2017). Israel Ranks Just behind US in Largest Income Inequality Rate. YNET.

OECD (2011). An Overview from Growing Income Inequalities in OECD Countries: Main Findings. https://www.oecd.org/els/soc/49499779.pdf

OECD (2016). Economic Survey on Israel. http://www.oecd.org/eco/surveys/Israel-2018-OECD-economic-survey-overview.pdf

OECD (2018). Economic Survey of Israel. http://www.oecd.org/israel/economic-survey-israel.htm

Parliamentary Committee of Inquiry on the Issue of Social Gaps in Israel (2002). Report and Survey of the Development of the Social Gaps in Israel in the Last Twenty Years.

Poch (2016). Israel Has Third Highest Gap between Rich and Poor in the World. Israel Post. https://www.israelnationalnews.com/News/News.aspx/206392

Ron, B. (2017). 60\% of Israeli Arabs Say They Are "Proud" to Be Israeli, Poll Shows, Israel Hayom.

http://www.israelhayom.com/2017/11/22/60-of-israeli-arabs-say-they-are-proud-to-beisraeli-poll-shows/

Sade, T. (2018). Income Gap in Israel One of Highest in OECD. Ynetnews. https://www.ynetnews.com/articles/0,7340,L-5303812,00.html

Schafferman, K. T. (2008). Israel: A Society of Immigrants, Israel Democracy Institution. https://en.idi.org.il/articles/6200

Senor and Singer (2009). Start-Up Nation: The Story of Israel's Economic Miracle, Ha- 
chette Group Us.

Solomon, S. (2018). The Blooming of the Desert: Key Stages of Israel's Economic Growth. Times of Israel.

https://www.timesofisrael.com/hold-for-wed-5-pm-the-growth-of-israels-economy-a-t imeline/

Tenkin, A. (2018). Arabs and Haredim Aren't the Issue. Globes.

http://en.globes.co.il/en/article-arabs-and-haredim-arent-the-real-problem-100124419 $\underline{8}$

US News (2017). Israel Overview. US News.

http://www.usnews.com/news/best-countries/israel

Wilfried Marshal Center for European Studies (2013). The Israeli Economic Miracle, Lessons for Europe.

https://www.martenscentre.eu/blog/israeli-economic-miracle-lessons-europe 